\title{
Economic analysis of up-to-date sour cherry orchards in Hungary
}

\author{
Apáti, F. \\ Department of Farm Business Management, Faculty of Agricultural Economics \\ and Rural Development, Centre for Agricultural Sciences and Engineering, University of Debrecen \\ 138 Böszörményi St., H-4032 Debrecen
}

Summary: In this study cost-profit analysis is carried out to up-to-date Hungarian sour cherry orchards. These orchards cover only 1 to 3 thousand hectares from the sour cherry territory of 16 thousand hectares. In a many-year-average a yield of 15 tons per hectare may be reached in up-to-date sour cherry orchards cultivated under high standard conditions. Per hectare direct production costs take up of approximately 1000 thousand HUF, from which the major portion $(60 \%)$ is accounted for the personal cost of harvesting. Regarding the above mentioned average yield and a selling price of $100 \mathrm{HUF}$ per kilogram a revenue of 1500 thousand HUF may be realized, which results in a per hectare contribution of 500 thousand HUF. To sum up, regarding the present extremely unfavourable selling price only reaching an average yield of 15 to 20 tons per hectare may lead to appropriate profit.

Key words: sour cherry, sour cherry orchard, economy of sour cherry production, cost-profit analysis

\section{Introduction}

Fruit production has an outstanding role in the Hungarian agriculture, which is proved by the fact that it ties down a significant number of labour and assets in billion HUF, and it contributes to the gross production value of crop production by 8 to $10 \%$ (Z. Kiss, 2003). Fruit production has a relevant significance in improving living standard of rural population in lagged behind regions where the conditions of production site is weaker (Papp, 1999).

The Hungarian vegetable and fruit enterprises do not even approach to its maximal performance. The level of the yields is low, many products of bad quality get into markets, the technology and variety-structure are out of date, and the domestic consumption is extremely low. Considering our future, it can be concluded that besides the previous mentioned, depressed technical standard, the segmentation of the production, the low level of co-operation, the sufficient storing capacity, and the presently low standard of service background helping in getting to markets are big disadvantages in competition. At the same time, the excellent nutrient content of our products, our comparative advantage in natural conditions and the favourable input-output relations originating from this, are advantages in the sharp competition (Lux, 2005).

On the basis of statistical data of the year 2001, Hungary has a sour cherry orchard of 16000 hectares, the total yield is between 40 and 70 thousand tones yearly. Regarding these data, the national average yield is 3 to 5 tons per hectare, which is rather low. Considering the general standard of our sour cherry production is not so easy; precise consequences cannot be made as the status of our orchards is extremely heterogenic (Hungarian Central Statistical Office (HCSO), 2001). Up-to-date orchards of excellent quality together with orchards of low quality producing inadequate products are present at the same time in our production.

An economic-marketing environment is expected to evolve in sour cherry production in Europe or even in the world, where the economic aspects of the production may be greatly influenced by the smallest prime cost reduction or yield growth of every one ton keeping the quality in the same level or making it improve. Yield drops caused by the extreme weather phenomena becoming more and more frequent due to the global climate change may contribute to all these. The economic and natural environments will probably be stricter, and will show an unfavourable tendency for farmers.

This tendency becoming stronger motivate European and Hungarian farmers for a greater competition, for using inputs in a reasonable way as well as for improving the natural efficiency of production.

The competitiveness is determined by the production efficiency (Marosán, 2001), thus the most important aim even in these orchards is the farm economic analysis. In this way our objectives were investigating the followings:

- roduction costs, cost structure,

- prime cost,

- output, production value,

- profit, profitability. 
In this study cost and profit conditions of up-to-date sour cherry orchards being in excellent status are modeled. Such an orchard is characterized by per hectare average yield of 10 to 20 tons, excellent quality (size, maturity) and high standard of inputs under normal conditions. These paramèters reflect not the Hungarian average but the best orchards, which take up of 1000 to 3000 hectares from the total 16000 hectares of orchards. From the point of view of the competitive production these orchards should be considered as standard and exemplary.

\section{Materials and methods}

In case of farm business research, the data collection is a general problem, mainly collecting the necessary information for cost examinations. As it can be strongly supposed that the majority of the ventures do not keep a detailed registration on the costs (counting reports are not clear from the point of view of economic analysis and they distort the reality), this problem was eliminated by the fact that we focused on not the cost but the inputs during our data collection that is on the natural quantity of resources utilized for the sake of the production.

The gained natural data mass could be turned into costs by evaluating the inputs on market prices. The major objective of this method is that the problem of difficulty in collecting data ceases as they can give precise information not on the costs of the farmers but the technology itself in natural values such as the carried out work, the average performance, as well as the utilized materials.

Data collection on production technologies in natural measures took place in producing ventures. The input prices of material inputs came from firms trading plant protecting agents and chemical fertilizers, prime costs of machine work were calculated from the service price of ventures lending machine work. Labour work was calculated on hourly wage typical to the region. Data collection happened in 2006 and 2007, thus input prices reflect price standards typical to these years without value added tax. Selling prices (output prices) were collected from trading ventures and producing and selling organizations.

Processing and evaluating data that is carrying out the cost-profit analysis happened by a simulation model.

\section{Results}

Before detailing the results, it is important to fix the parameters of the orchard type selected for the basis of the analysis: Mahaleb rootstock, funnel-shaped crown form and $6,0 \times 4,0 \mathrm{~m}$ spatial position, which equals with 417 trees per hectare. These parameters reflect a traditional orchard, which is dominant in Hungary in comparing to the intensive one. The used cultivars are mainly those which are most frequently used in Hungary ('Újfehértói fürtös', 'Kántorjánosi', 'Debreceni bôtermô').
In this economic evaluation we highlight and characterize a year which is considered as ordinary, which means that the introduced calculations relate to a normal year free from greater positive and negative weather and plant protecting extremes and suppose a production technology of excellent standard and strict technological discipline.

A very important thing: the introduced calculations cannot be accepted as the only one truth, do not relate to everyone and everything (as costs and revenues are different in every enterprise, in every orchard and in every year), but the order of the calculations reflect truly the reality.

In the next part the cost and profit conditions are introduced in a way that was mentioned before.

\section{Production Cost}

When studying the cost structure of sour cherry production through the phases (Table I), it reveals that harvesting is far the most outstanding phase which is accounted for $60 \%$ of the costs. Plant protection contributes to costs by $15 \%$, the cost modifying role of the other phases is not so determent.

Table 1 The Costs of Sour Cherry Production by Working Phases (Per Hectare)

- Calculated on high technological standard not on national average -

\begin{tabular}{|l|c|c|}
\hline \multicolumn{1}{|c|}{ Phases } & $\begin{array}{c}\text { Cost } \\
\text { (thousand HUF/ha) }\end{array}$ & $\begin{array}{c}\text { Distribution } \\
(\%)\end{array}$ \\
\hline Pruning & 62 & 6 \\
\hline Soil and row cultivation & 16 & 2 \\
\hline Fertilizing & 70 & 7 \\
\hline Plant protection & 153 & 15 \\
\hline Harvesting & 618 & 61 \\
\hline Depreciation of the orchard & 87 & 9 \\
\hline Direct production cost & $\mathbf{1 0 0 6}$ & $\mathbf{1 0 0}$ \\
\hline
\end{tabular}

Source: on the basis of data collection of Apáti, F., own calculation

Although the depreciation of the orchard may not be considered as a phase in a strong meaning, as it is the value of the investment cost calculated to one year of the operation, it should be listed here for the sake of the complexity by all means.

In the following part, the structure of the costs and the more important technological factors relating to this are looked through in the order of Table 1.

Pruning has not so much significance in case of sour cherry orchards than in an intensive apple orchard for example, its regular completion is essential in order to maintain stable yields for a long term. Its cost includes the labour work of pruning and collecting loppings as well as the machine phase of crushing loppings. The time need of pruning depends on several factors and fluctuates yearly to a great extent. In most of the years only a smaller correction is necessary when 100 to 120 working hour may be calculated to one hectare, which may be increased by the phases of 
collecting loppings by 15 to 20 working hour. In this way pruning costs include personal cost of 90 to $95 \%$ and machine cost of 5 to $10 \%$.

Utilizing grassed row space is pervading in sour cherry orchard, the tree lines are kept clean by chemical weed control. Thus the soil and row cultivation means mowing grass 4 to 6 times a year. In orchards of non-grassed rows mechanical soil cultivation is carried out once or twice (fertilizing, soil milling, loosening), which may be supplemented by mechanic mowing for three of four times. The costs of the phases are not relevant in either of the cases, take up of 2 to $3 \%$ of the production costs and include only machinery cost.

The cost of fertilizing consists of the input of chemical fertilizing; organic fertilizer is hardly used in practice. The fertilizing cost in Table 1 includes only chemical fertilizing, adding complex chemical fertilizer of 400 to 600 kilograms per hectare with $\mathrm{P}$ and $\mathrm{K}$ dominance and $\mathrm{N}$-fertilizer of 200 to 300 kilograms per hectare as well as top-dressing for 4 to 5 times (especially $\mathrm{N}$ and micro elements). $90 \%$ of the total cost is material cost and the remaining part is accounted for the labour and machinery work of loading, transportation and dispersion.

Plant protection is the second biggest cost from the production costs by $15 \%$. It is a relevant feature of the phase that only a single small mistake may cause damages in quality and quantity or even the whole yield may be destroyed (mainly during blooming because of Monilia infection). Approximately $80 \%$ of the plant protecting cost goes for spraying and $20 \%$ for weed control, which may contain mowing to a small degree. 25 to $30 \%$ of plant protection is machinery cost, while 70 to $75 \%$ is material cost. Pesticides take up of $35 \%$, fungicides are responsible for $50 \%$ and herbicides constitute $15 \%$ of the material cost. 6 to 9 sprayings are necessary yearly in order to save the yield depending on the infection condition (three sprayings in the period of blooming), in this way the average cost of one spraying is between 13 to 20 thousand HUF.

Harvesting in the practice of our sour cherry production means manual picking in general, though we speak about sour cherry for industrial purposes, at present the ratio of yields sold to fresh market is minimal. The picking performance in average is 150 kilograms per capita per day if the basis of waging is the performance. This means that for harvesting the 15 tons per hectare yield in the calculation, 200 labour days or 800 working hours are necessary. This personal cost of 600 thousand HUF is supplemented by the costs of labour and machinery work of 20 thousand HUF including loading and transporting bundles and delivering and loading the harvest.

When wages are paid on the basis of time much smaller performance may be reached according to experiences, approximately 80 to 100 kilograms per capita per day. In general, waging performance may be used if the quality does not decline over against performance. Using this wage form is unfavourable for the cost of harvesting of sour cherry as during carrying out the phases mistakes causing quality damages cannot be made.
If the sour cherry is sold not for industrial purposes but for fresh market, the harvest should be picked by the stems, which decreases the picking performance to a great extent. In this case only 60 to 70 kilograms per capita per day may be measured. This significantly increases the costs of harvesting.

Machinery harvesting may have significant performance improving and cost reducing effects in case of sour cherry for industrial purposes, but in sour cherry for fresh market only manual harvesting may be used.

After the cost structure of sour cherry production in phases, in the next part the cost type structure is investigated.

Table 2 shows the 1006 thousand HUF per hectare production costs in cost types detailed previously in phases. This is supplemented by the overhead cost for the sake of completeness. Its ratio is 5 to $15 \%$ of the total production cost depending on the size, production structure, the management, etc. of the venture. The total production cost of sour cherry production is about 1100 thousand HUF.

The most significant cost is the personal cost in sour cherry production constituting $60 \%$ from the total production cost. This is followed by the material cost contributing by $15 \%$ to the production cost. Machinery cost and depreciation cost represent almost a same ratio by 7 to $8 \%$. Other direct costs (insurance cost, land rent) were not calculated as they are not typical, but if they incur the production cost may be increased by 100 to 150 thousand HUF.

Table 2 Costs of Sour Cherry Production by Cost-Type-Structure (per hectare)

- Calculated on high technological standard not on national average -

\begin{tabular}{|l|c|c|}
\hline \multicolumn{1}{|c|}{ Denomination } & $\begin{array}{c}\text { Cost } \\
\text { (thousand HUF/ha) }\end{array}$ & $\begin{array}{c}\text { Distribution } \\
(\%)\end{array}$ \\
\hline Material cost & 167 & 15 \\
\hline Labour cost & 673 & 61 \\
\hline Machinery cost & 79 & 7 \\
\hline Depreciation of orchard & 87 & 8 \\
\hline Other direct cost & 0 & $\mathbf{9 1}$ \\
\hline Direct production cost & $\mathbf{1 0 0 6}$ & 9 \\
\hline Overhead cost & 96 & $\mathbf{1 0 0}$ \\
\hline Total production cost & $\mathbf{1 1 0 2}$ & 0 \\
\hline
\end{tabular}

Source: on the basis of data collection of Apáti, F., own calculation

Material costs (Table 3) include only the costs of plant protecting agents and chemical fertilizers, from which the ratio of plant protecting agents is higher constituting two third of the material costs. It is a basic truth that the savings in case of plant protecting costs are not in proportion with the revenue reduction coming from the quality decline, thus it is worth giving higher inputs in order to save the harvest.

The ratio of chemical fertilizers is not negligible either as the average yields of 10 to 20 tons per hectare require 600 to 900 kilograms chemical fertilizers per hectare, which approximately equals with 200 to 300 NPK agents. 
Table 3 The Structure of Material Costs in Sour Cherry Production - Calculated on high technological standard not on national average -

\begin{tabular}{|l|c|c|}
\hline \multicolumn{1}{|c|}{ Denomination } & $\begin{array}{c}\text { Cost } \\
\text { (thousand HUF/ha) }\end{array}$ & $\begin{array}{c}\text { Distribution } \\
(\%)\end{array}$ \\
\hline Material cost & 167 & 15 \\
\hline $\begin{array}{c}\text { Chemical fertilizer } \\
\text { Plant protecting agent }\end{array}$ & 62 & 37 \\
\hline Total material cost & 105 & 63 \\
\hline
\end{tabular}

Source: on the basis of data collection of Apáti, F., own calculation

Table 4 Structure of Labour Costs in Sour Cherry Production - Calculated on high technological standard not on national average -

\begin{tabular}{|l|c|c|}
\hline \multicolumn{1}{|c|}{ Denomination } & $\begin{array}{c}\text { Cost } \\
\text { (thousand HUF/ha) }\end{array}$ & $\begin{array}{c}\text { Distribution } \\
(\boldsymbol{\%})\end{array}$ \\
\hline Material cost & 167 & 15 \\
\hline Pruning & 58 & 9 \\
\hline Fertilizing & 3 & 0 \\
\hline Plant protecting spraying & 0 & 0 \\
\hline Manual weed control & 7 & 1 \\
\hline Chemical weed control & 0 & 0 \\
\hline Picking & 600 & 89 \\
\hline Loading, transportation & 5 & $\mathbf{1 0 0}$ \\
\hline Total labour cost & $\mathbf{6 7 3}$ & 1 \\
\hline
\end{tabular}

Source: on the basis of data collection of Apáti, F., own calculation

Only the cost of picking takes up of $90 \%$ of labour cost (Table 4). This cost type, however, depends wholly on yields (that is this cost as a whole is a variable cost) thus this distribution may be modified if yields are changed. Other labour work besides pruning belonging to the maintenance of the orchard does not represent a significant part. The only determining phase is picking.

Regarding the fact that only the cost of picking as a variable cost constitutes $60 \%$ of the direct cost, the major part of the production cost is considered as variable. This explains one of the very relevant farm business features of sour cherry production, which is detailed later.

The machinery needs of plant protection, soil and row cultivation and harvesting (transportation and loading) are outstanding from machinery costs (Table 5). The requirement for the machinery working hour depends significantly on yields in this way it is considered as a variable cost. Carrying out the other machinery phases is independent from yields, but their order is not dominant within the production costs.

To sum up the issue of production costs, sour cherry production does not belong to fruit sectors of relatively high production cost, as the standard of inputs is not very high. Approximately $70 \%$ of the costs are variable depending fully on yields; in this way it is not the high input need but the quantity of yields which determines the cost.
Table 5 The Structure of Machinery Costs in Sour Cherry Production - Calculated on high technological standard not on national average -

\begin{tabular}{|l|c|c|}
\hline \multicolumn{1}{|c|}{ Denomination } & $\begin{array}{c}\text { Cost } \\
\text { (thousand HUF/ha) }\end{array}$ & $\begin{array}{c}\text { Distribution } \\
(\boldsymbol{\%})\end{array}$ \\
\hline Material cost & 167 & 15 \\
\hline Crushing loppings & 4 & 5 \\
\hline Soil and row cultivation & 16 & 20 \\
\hline Fertilization & 5 & 6 \\
\hline Plant protecting spraying & 35 & 45 \\
\hline Chemical weed control & 6 & 7 \\
\hline Harvesting (loading, transportation) & 13 & 17 \\
\hline Total machinery cost & $\mathbf{7 9}$ & $\mathbf{1 0 0}$ \\
\hline
\end{tabular}

Source: on the basis of data collection of Apáti, F., own calculation

\section{Production Value}

When investigating production value, the first step is to analyze selling prices as they are different yearly to a significant degree, fluctuate in a hectic way basically determining the profit conditions of the production.

The problem of the sour cherry market is not the continuous and permanent overproduction but the extremely rate and incalculable hectic fever of the market year by year and even within the season. Further feature of the sour cherry chain is that this is basically for industrial purposes, which means that only a very small portion of the harvest ( 5 to $10 \%$ ) are sold in fresh market, the major part gets into processing industry and cold-storage industry.

The hectic fever of sour cherry market can be illustrated by the tendency of the price of sour cherry. As Figure 1 shows the producer's prices reflect an extreme fluctuation (400 to $500 \%$ ) during the past eight years. This fluctuation makes the future incalculable and unpredictable, though these would be basic aspects in case of such a permanent culture. One of the most serious developmental barriers of the sector is the instability of the market. Besides this the low standard of selling price in a permanent way experienced during the past years (except for 2003) is negative from the point of the of the future image, which does not make the maintenance of profitability to even a minimal level possible.

The incalculable feature and instability of the market may be experienced not only year by year but within a certain year, more precisely within a 4 to 5 -week-long season. The year 2006 (Figure 2) is an excellent example, which basically characterizes the tendencies within the season in other years.

The market of the sour cherry starts with prices above the seasonal average; early ripening cultivars are sold by good prices then by starting picking the late ripening cultivars as main cultivars the sour cherry market 1 to 2 weeks after the start of sour cherry purchase collapses. This basically means a price decline of 40 to $60 \%$. The major reason of this shortterm incalculable feature is the one-sided structure of 


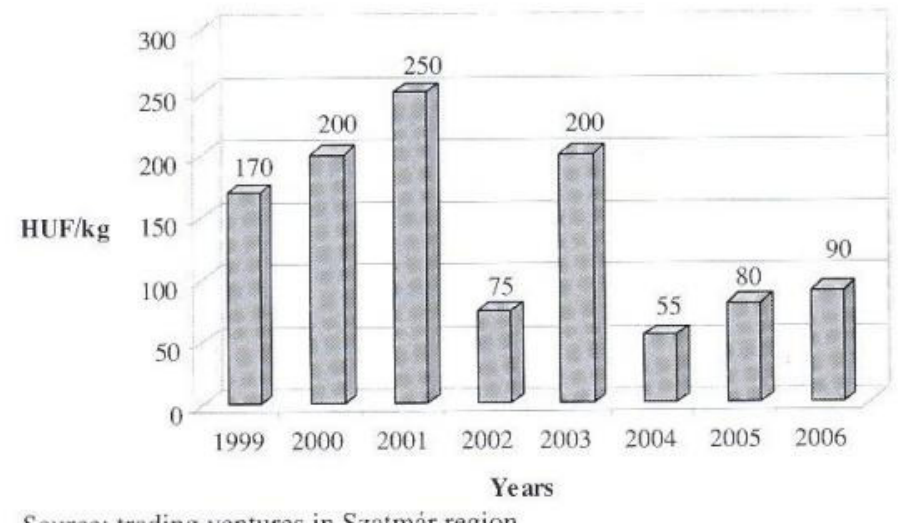

Source: trading ventures in Szatmár region

Figure 1 The Gross Producer's Average Price of Sour Cherry for Industrial Purposes between 1999 and 2006

Hungarian cultivars, which is proved by the fact that 80 to $90 \%$ of the harvest is produced by three main varieties ('Újfehértói fürtös', 'Kántorjánosi', 'Debreceni bốtermő') ripening in the same period thus great amount of sour cherry overflows the market rapidly, all at once.

It is clear now that the revenue of the production differs to a great extent year by year because of the highly fluctuating prices. When planning the future the most difficult task is always the selection of prices. In our calculation a price of 100 HUF per kilogram was fixed being appropriate for a long-term average.

Table 6 reflects the revenue calculation typical to sour cherry production. The major part of the harvest of 15 tons per hectare is for industrial processing, the ratio of sour cherry being sold in fresh market does not exceed the 5 to $10 \%$. In the majority of ventures industrial selling is typical in $100 \%$; today only few ventures undertake the further input need of selling in fresh market and the difficulties of selling in smaller volume and neither the market requires in much more volume. Selling happens immediately after picking.

Regarding every factor per hectare revenue of 1.5 million HUF may be reached in sour cherry production. It is essential that this value may reflect a significant fluctuation year by year. In a long term view a further key factor is the yield safety: there were total frost damages in many production sites in three years of the last six years (because of two winter frosts and one spring frost), which heavily worsens the profitability of the production for a long term.

Table 6 Production Value in Sour Cherry Production - Calculated on high technological standard not on national average -

\begin{tabular}{|l|c|c|}
\hline \multicolumn{1}{|c|}{ Denomination } & Unit & Value \\
\hline Material cost & 167 & 15 \\
\hline Total yield & t/ha & 15,0 \\
\hline Selling price & HUF/kg & 100,0 \\
\hline Total revenue & thousand HUF & 1500,0 \\
\hline SAPS & thousand HUF & 18,0 \\
\hline Production value & thousand HUF & $\mathbf{1 5 1 8 , 0}$ \\
\hline
\end{tabular}

Source: on the basis of data collection of Apáti, F., own calculation

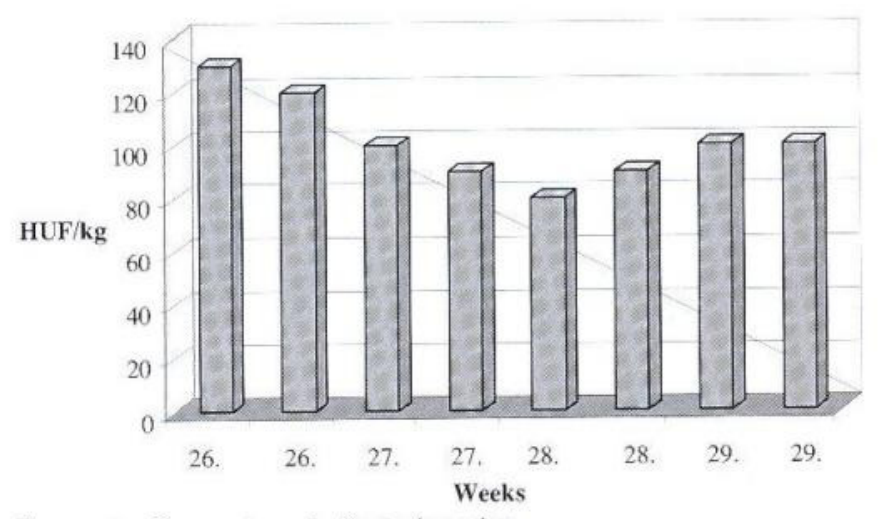

Source: trading ventures in Szatmár region

Figure 2 Producer's Price of Sour Cherry for Industrial Purposes in 2006, Within the Season

Basically there are two direct payments in sour cherry production which can be calculated. The value of the SAPS is rather low (18 to 20 thousand HUF per hectare), while agricultural-environmental subsidy for the method of environmental friendly production is near 100 thousand HUF per hectare which cannot be neglected from the production value, but here and now it was not calculated. Aggregating revenue and subsidies a production value of 1.5 million HUF is reached, which may be considered as an average value for ventures producing on good standard.

\section{Profit, Profitability}

The basic aim of farming is to maximize profit, in this way the reachable profit is the most emphasized aspect. The profit from farm business aspects is the difference between production value and production cost. The obligation to pay income tax is neglected thus it is a profit before taxation.

Table 7 shows the calculation of profit by using the data of the already introduced production cost and production value. Summarizing the data of sour cherry production a contribution of 500 thousand HUF may be expected from ventures producing on good standards under normal conditions (Table 7).

Table 7 Profit in Sour Cherry Production - Calculated on high technological standard not on national average -

\begin{tabular}{|l|c|c|}
\hline \multicolumn{1}{|c|}{ Denomination } & Unit & Value \\
\hline Material cost & 167 & 15 \\
\hline Production value & thousand HUF & $\mathbf{1 5 1 8 , 0}$ \\
\hline Direct production cost & thousand HUF & 1006,0 \\
\hline Contribution & thousand HUF & $\mathbf{5 1 2 , 0}$ \\
\hline Overhead cost & thousand HUF & 96,0 \\
\hline Total production cost & thousand HUF & 1102,0 \\
\hline Net profit & thousand HUF & $\mathbf{4 1 6 , 0}$ \\
\hline Cost rated profitability & $\%$ & 50,9 \\
\hline
\end{tabular}

Source: on the basis of data collection of Apáti, F., own calculation 
Regarding the overhead costs a net profit of 400 thousand HUF may be reached. If the tendency of selling prices and yields is favourable, the contribution may exceed 1 million HUF. On the other hand, it may occur that the contribution reflects a negative tendency because of low prices and low yields.

\section{Conclusions}

The major conclusions of the cost-profit analysis above introduced are summarized as follows.

$70 \%$ of the production costs are variable cost depending fully on yields (just the harvesting cost is accounted for $60 \%$ of the total costs). The consequences of this are an advantageous and a disadvantageous feature.

- The advantage is in the fact that production costs are much lower by the low yields (as they depend on yields in $70 \%$ ), thus too much damages do not have to be coped with even in case of lower harvest.

- Only small rate prime cost reduction may be reached by increasing yields, which is a disadvantageous fact, as costs grow together with yields.
The up-to-date orchards are suitable for reaching adequate profit level, but it is clear that this is only possible by reaching a per hectare yield of 15 to 20 tons under the rather unfavourable selling price standards. In this way the destiny and competitiveness of orchards being able to realize only per hectare yield of 4 to 5 tons is problematic.

\section{References}

KSH. (2001): Gyümölcsültetvények Magyarországon. KSH. Budapest, 2002. 170-173., 242-245.

Lux R. (2005): A kertészet fejlesztési lehetốségei. Stratégiai munkaanyag, Fruitveb Magyar Zöldség-Gyümölcs Szakmaközi Szervezet, Budapest.

Marosán Gy. (2001): Stratégiai menedzsment. Múszaki Könyvkiadó. Budapest. 106-117. p.

Papp J. (1999): Az EU-összehasonlításban versenyképes kertészeti ágazatok fejlesztési koncepciójának alapjai. In: Versenyképes kertészeti ágazatok fejlesztési koncepciójának alapjai - Stratégiai kutatások a Magyar Tudományos Akadémián. (Szerk.: Papp J.) Agroinform Kiadó. Budapest, 1999. 8-14. p.

Z. Kiss L. (2003): A gyümölcstermesztés feltételrendszere. In.: A gyümölcstermesztés, -tárolás, -értékesítés szervezése és ökonómiája. (Szerk. Z. Kiss). Mezốgazda Kiadó. Budapest. 13. p. 